Journal of Health Promotion and Behavior (2016), 1(3): 212-223

https://doi.org/10.26911/thejhpb.2016.01.03.08

\title{
Analysis of the Effect of Maternal Perception on Completeness of Child Immunization Status with Health Belief Model
}

\author{
Yessica Eka Puri'1), Bhisma Murti'1), Argyo Dermatoto²) \\ 1)Masters Program in Public Health, Universitas Sebelas Maret \\ 2)Faculty of Social and Political Sciences, Universitas Sebelas Maret
}

\begin{abstract}
Background: The child immunization coverage was low in several health centers in Surakarta, Central Java. Some of the health centers did not achieve GAIN Universal Child Immunization (UCI) target in 2014, for example, Penumping Health Center (HBV $<7$ days $=86.9 \%$, BCG $=87.8 \%$, Campak= 87.5\%, DTP-HBV-HIB= 86.7\%, Polio= 87.5\%) and Banyuanyar Health Center (Measles= 89.6\%). This study aimed to determine the effect of maternal perception on completeness of child immunization status using Health Belief Model (HBM).

Subjects and Method: This was an analytic observational study with case control design. It was conducted at Penumping and Banyuanyar Health Centers, Surakarta, Central java. A total sample of 120 mothers and their respective children aged $<9$ years was selected for this study by fixed disease sampling. This sample consisted of children with complete immunization and the other children with incomplete immunization (ratio=1:4). The dependent variable was completeness of immunization status. The independent variables were maternal perception on various HBM constructs, including perceived susceptibility, seriousness, threat, benefit, and barrier. The data were collected by a set of questionnaire, and analyzed by path analysis.

Results: Perceived susceptibility had indirect and positive effect on completeness of immunization status via perceived threat, although it was not statistically significant $(b=0.63 ; 95 \% \mathrm{CI}=-0.13$ to 1.39; $\mathrm{p}=0.104)$. Perceived seriousness had indirect positive and statistically significant effect on completeness of immunization status via perceived threat $(b=1.10 ; 95 \% \mathrm{CI}=0.71$ to $3.04 ; \mathrm{p}=$ 0.005). Perceived threat $(b=1.88 ; 95 \% \mathrm{CI}=0.34$ to $1.86 ; \mathrm{p}=0.002)$, and perceived benefit $(\mathrm{b}=1.83$; $95 \% \mathrm{CI}=0.69$ to $2.96 ; \mathrm{p}=0.002$ ), showed direct positive and statistically significant effect on completeness of immunization status. Perceived barrier had direct and negative effect on completeness of immunization status ( $b=-0.96 ; 95 \% \mathrm{CI}=-1.97$ to $0.05 ; \mathrm{p}=0.063$ ).

Conclusion: Maternal perception on child susceptibility, disease seriousness, disease threat, benefit and barrier of immunization, have effects on the completeness of immunization status.
\end{abstract}

Keywords: immunization status, completeness, health belief model

\section{Correspondence:}

Yessica Eka Puri. Masters Program in Public Health, Universitas Sebelas Maret. Jl. Ir. Sutami 36A, Surakarta 57126, Central Java. Mobile: 087856408766.

\section{BACKGROUND}

Immunization programs are very important for individuals to create immunity to avoid disease so that community immunity is achieved, but there are still many immunization problems in the world and Indonesia. Diseases that can be prevented by immunization (PD3I), for example tuberculosis (TB), diphtheria, pertussis, tetanus, measles, polio and hepatitis B. Immuniza- tion is estimated to prevent 2.5 million cases of child deaths per year worldwide. UNICEF said that 27 million children under five throughout the world still have not received routine immunization services, causing more than two million deaths each year. This figure includes 1.4 million children under five who were killed. Indonesia is one of the 10 countries that are among the highest numbers in the case of unimmu- 
nized children, namely around 1.3 million children (Ismet, 2013; Kadir et al., 2014; Probandari et al., 2013).

The Government through the Health Service has made efforts to improve immunization outcomes. Immunization achievement in Indonesia until December 2014 was $86.9 \%$. The immunization achievement in Central Java until December 2014 was 93.3\%. immunization achievement in the city of Surakarta alone is $96.3 \%$. This figure shows that immunization achievements in Surakarta City have been very good. However, if detailed, there are still villages that have not met the UCI GAIN target in 2014, namely the percentage of infants aged o-11 months who get complete basic immunization 90\%. Among 17 Health center Work Areas in Surakarta City, there are two Health center Work Areas that have not met the GAIN UCI target, namely Penumping Health center and Banyuanyar Health center. In Health center Penumping, $\mathrm{Hb}$ immunization coverage $<7$ days: $86.9 \%$, BCG: $87.8 \%$, Measles: 87.5\%, DPT-Hb-Hib: 86.7\%, Polio: 87.5\%. Whereas in Banyuanyar Health center, $\mathrm{Hb}$ immunization coverage <7 days: 92.8\%, BCG: $92.8 \%$, Measles: 89.6\%, DPT-Hb-Hib: 93.9\%, Polio: 92.9\%. In Banyuanyar Health center only measles immunization has not met the GACI UCI target of $89.6 \%$. The cause of immunization achievement targets has not been met, one of which is the perception of parents or caregivers about immunization. (Surakarta Health Office, 2014; Republic of Indonesia Ministry of Health, 2010; Republic of Indonesia Ministry of Health, 2014 a; Ministry of Health Republic of Indonesia, 2015).

The Health Belief Model (HBM) theory develops to answer health problems that have been pursued optimally from various parties but have been less successful. This theory talks about the perception that people have that can influence their health behavior.

Parents' perceptions can be different for each individual. This can be due to the differences in character which is also formed from differences in demographics. In this study, the relationship between parents' beliefs about vaccination was evaluated, their decision to postpone or refuse vaccination for their children, and immunization coverage for children aged 24 months. From the phenomenon above, researchers realize the importance of conducting a study on the effect of maternal perceptions of immunization reviewed with Health Belief Model on the completeness of immunizations in Surakarta.

\section{SUBJECTS AND METHOD}

This study is an epidemiological observational study with a Case Control Study research design, an epidemiological study that studies the relationship between exposure (research factors) and disease, by comparing case and control groups based on their exposure status. The sampling technique used is the fix disease sampling technique in the ratio (1: 3 ) with 24 case control subjects and 96 control subjects. The exogenous variables are perception of vulnerability, seriousness, benefits and obstacles. The endogenous variables are threat perception and completeness of immunization status. The analysis used was path analysis.

The characteristics of the subjects based on maternal age, education and occupation were divided into two subjects, namely the case subjects with results, the majority of mothers (20-39 years old) were 22 people (91\%), the majority of them was D4-S1 of 16 people (68\%), most of them do not work namely 14 people $(58.5 \%)$. The second one was the control subjects, the majority of mothers were 20-39 years old of 87 people (90\%), the majority of mothers 
was D4-S1 graduates namely 61 people workers of 68 people (71\%). $(63.5 \%)$, most of them work as private

Table 1. The characteristics of the Subjects Based on Age, Education and Occupation of Mothers

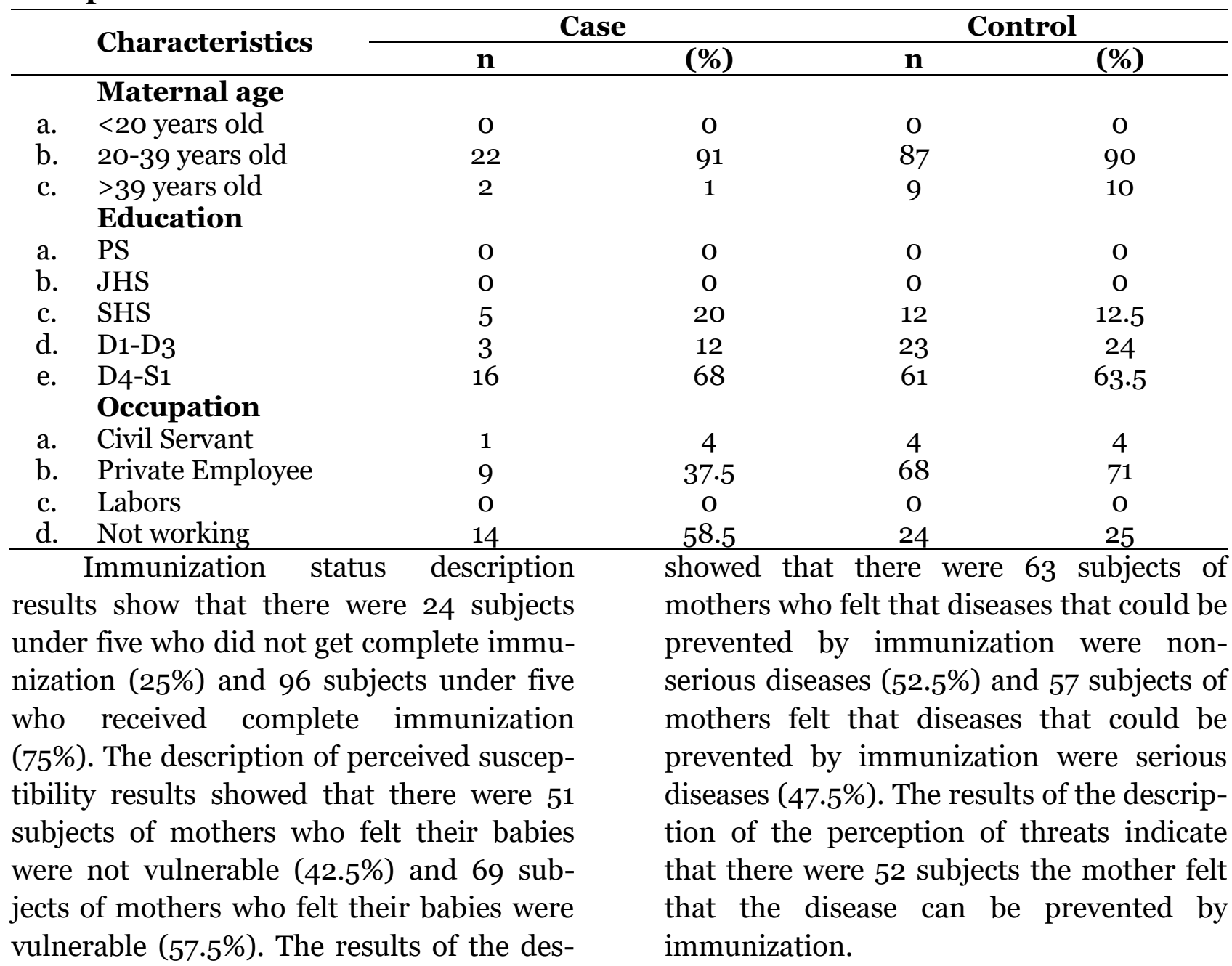
cription of the perception of seriousness

Table 2. Results of path analysis of the effect of mother's perception on health belief model against completeness of immunization status

\begin{tabular}{|c|c|c|c|c|c|c|}
\hline \multirow[b]{2}{*}{$\begin{array}{c}\text { Dependent } \\
\text { variable }\end{array}$} & & \multirow[b]{2}{*}{$\begin{array}{c}\text { Independent } \\
\text { variable }\end{array}$} & \multirow{2}{*}{$\begin{array}{c}\text { Path } \\
\text { Coefficient } \\
\text { (b) }\end{array}$} & \multicolumn{2}{|c|}{$95 \% \mathrm{CI}$} & \multirow[b]{2}{*}{$\mathbf{p}$} \\
\hline & & & & $\begin{array}{l}\text { Lower } \\
\text { Limit }\end{array}$ & $\begin{array}{l}\text { Upper } \\
\text { Limit }\end{array}$ & \\
\hline \multicolumn{7}{|l|}{ Direct Effect } \\
\hline Immunization & $\leftarrow$ & Perceived threat & 1.88 & 0.71 & 3.04 & 0.002 \\
\hline completeness & $\leftarrow$ & Perceived benefit & 1.83 & 0.69 & 2.96 & 0.002 \\
\hline & $\leftarrow$ & Perceived barrier & -0.96 & -1.97 & 0.05 & 0.063 \\
\hline \multicolumn{7}{|l|}{ Indirect Effect } \\
\hline Perceived threat & $\leftarrow$ & Perceived susceptibility & 0.63 & -0.13 & 1.39 & 0.104 \\
\hline & $\leftarrow$ & Perceived seriousness & 1.10 & 0.34 & 1.86 & 0.005 \\
\hline
\end{tabular}

Non-threatening diseases were $45 \%)$

and 66 maternal subjects felt that diseases that could be prevented by immunization were threatening diseases (55.0\%). The results of the description of perceived usefulness indicate that there are 43 subjects 
the mother feels immunization is not beneficial for her baby (35.8\%) and 77 subjects the mother feels immunization is beneficial for her baby (64.2\%). The results of the description of the perception of obstacles indicate that there are 46 subjects the mother feels there is no obstacle in immunizing her baby (38.3\%) and 74 subject mothers feel there are obstacles in immunizing their baby (61.7\%). The results of the path analysis of the effects of perception of vulnerability, seriousness, threats, benefits and obstacles to the completeness of immunization status are described in Table 2.

\section{DISCUSSION}

The indirect effect between perception of vulnerability and completeness of immunization status is obtained from the first effect, namely between perception of vulnerability and perception of threat $(b=0.63$; $95 \% \mathrm{CI}=-0.13$ to $1.39 ; \mathrm{p}=0.104)$, then proceed from threat perception to completeness of status immunization $(\mathrm{b}=1.88$; $95 \% \mathrm{CI}=0.71$ to $3.04 ; \mathrm{p}=0.002$ ). It can be concluded that there is an indirect effect between perception of vulnerability and completeness of immunization status through threat perception. Mothers who have a perception that their babies are vulnerable to experience diseases that can be prevented by immunization are more likely to immunize their babies than mothers who have the perception that their babies are not susceptible to diseases that can be prevented by immunization.

The results of this study are in line with the study of Smith et al. (2011) which revealed that parents who refused vaccination were less likely to believe that vaccination was needed to protect the health of their children compared to parents who gave vaccinations to their children. If someone feels at risk of an illness then he will carry out safe behaviors and preventive measures (Hayden, 2010). According to Rosenstock (1982) in Noorkasiani (2009), those who feel they can be affected by the disease will feel threatened faster. This threat encourages individuals to take action to prevent or cure disease.

The results of this study indicate that there are still mothers who feel that their babies are not susceptible to disease (42.5\%). Perceived vulnerability is often referred to as motivation in taking a health action because they do not believe that their child will not be attacked by disease. If a person feels not susceptible to the disease, it is necessary to provide more intensive stimulation so that he also triggers the desired response that is to carry out immunizations. The perceived low vulnerability to a disease can be caused by lack of knowledge about the dangers of the disease. Therefore additional research is needed on vulnerability perceptions in relation to maternal knowledge about diseases that can be prevented by immunization.

There is a positive relationship between perception of seriousness and the completeness of immunization status. The indirect effect between perception of seriousness and completeness of immunization status is obtained from the first effect, which is between perception of seriousness and threat perception $(b=1.10$; 95\% CI $=0.34$ to $1.86 ; \mathrm{p}=0.005$ ), then proceed from threat perception to completeness of immunization status $(b=1.88$; 95\% CI $=0.71$ to $3.04 ; \mathrm{p}=0.002$ ). There is an indirect effect between perception of seriousness and completeness of immunization status through threat perception. Mothers who have the perception that diseases that can be prevented by immunization are serious diseases, are more likely to immunize their babies than mothers who have the perception that diseases that can 
be prevented by immunization are not serious diseases.

The results of this study agree with several existing theories about the Health Belief Model. Hayden (2010) states that the perceived seriousness determines the presence or absence of preventive measures taken against the disease. The perception of seriousness is often based on medical information or knowledge, it can also come from a person's belief that he will get into trouble due to illness and will make or have an effect on his life in general (Priyoto, 2014). Those who feel that diseases that can be prevented by immunization such as hepatitis, diphtheria, pertussis, tetanus, measles and polio are serious diseases, they will feel threatened more quickly. This threat encourages individuals to take action to prevent or cure disease (Rosenstock, 1982 in Noorkasiani, 2009).

The perceived seriousness determines whether or not any preventive action is taken against the disease. Data obtained from this study indicate that there are still mothers who perceive that diseases that can be prevented by immunization such as hepatitis, diphtheria, pertussis, tetanus, measles and polio are not serious and threatening their babies (52.5\%) and decided not to immunize his child. This is due to the fact that vaccines themselves have not been the first choice in disease prevention due to lack of knowledge about the dangers of the disease. Additional research is needed on the perception of seriousness in relation to maternal knowledge about diseases that can be prevented by immunization.

There was a positive influence between perceived threat and completeness of immunization status $(\mathrm{b}=1.88 ; 95 \% \mathrm{CI}=$ 0.71 to $3.04 ; \mathrm{p}=0.002$ ). That is, mothers who have the perception that diseases that can be prevented by immunization are diseases that threaten the health of their babies, are 1.88 more likely to immunize their babies than mothers who have the perception that diseases that can be prevented by immunization are not diseases that threaten the health of their babies.

According to Rosenstock (1982) in Noorkasiani (2009), individuals' perceptions about their likelihood of being exposed to a disease (perceived susceptibility) make them more quickly feel threatened. The individual's view of the severity of the disease (perceived seriousness), namely the risks and difficulties that will be experienced from the disease makes it likely that the individual feels will be easily attacked by the disease. This causes increasingly greater perceived threat (perceived threats). This threat encourages individuals to take action to prevent or cure disease.

The results of the study show that mothers who think that diseases that can be prevented by immunization are diseases that do not threaten their babies (45\%). This is because the understanding of the threats that can be caused by diseases that can be prevented by each individual's immunization is different, depending on his medical knowledge about the disease. It would be better if a study was conducted on the perception of threats in relation to the mother's knowledge about diseases that can be prevented by immunization so that the effect of knowledge on the perception of disease threats can be known.

There was a direct positive effect between perceived benefits and completeness of immunization status $(b=1.83 ; 95 \%$ $\mathrm{CI}=0.69$ to $2.96 ; \mathrm{p}=0.002$ ). Mothers who have the perception that infant immunizations are beneficial have a 1.83 greater chance to immunize their babies than mothers who have the perception that infant immunizations are not beneficial. 
The results of this study are in line with the study of Smith et al. (2011). This study shows that parents who disagree with their children being given the vaccine feel less of the benefits associated with vaccines. Parents who agree with vaccines consider vaccination to be beneficial for their child's health. Perceived benefits are one's opinions about the value or usefulness of a new behavior in reducing disease risk. Someone will tend to implement healthy behaviors when he feels the behavior is beneficial to reduce cases of the disease. This study shows that a person will carry out the vaccination if he feels the action is beneficial and vice versa, so that the presentation of the mother who does not immunize her baby is still found because the mother does not feel the benefits of the immunization. The perception of the benefits of immunization has not been felt directly, especially for mothers who do not immunize their children because the vaccine, according to him, is not effective in preventing disease.

The immunization of infants not only provides prevention of certain diseases to the child but also has a wider impact because it can prevent transmission of the disease to others. Therefore, the knowledge and attitude of parents, especially mothers, is very important to understand the benefits of immunization for their babies.

There is a negative influence between the perception of the direct obstacle to the completeness of immunization status $(b=-$ $0.96 ; 95 \% \mathrm{CI}=-1.97$ to $0.05 ; \mathrm{p}=0.063)$. Mothers who have the perception that there are many obstacles when immunizing their babies are 0.96 less likely to immunize their babies than mothers who have the perception that there are no obstacles when immunizing their babies.

Perception of obstacles is the obstacle felt by the mother when she wants to take the decision to immunize her baby. Barriers in this study mean that there are distance constraints, maternal anxiety, and norm / cultural barriers. Perceived barriers relate to the individual's own evaluation process for the obstacles faced to adopt new behaviors. Perception about the obstacles that will be felt is a significant element in determining whether there is a change in behavior or not. Regarding the new behavior to be adopted, one must believe that the benefits of the new behavior outweigh the consequences of continuing the old behavior. This allows obstacles to be overcome and new behaviors to be adopted (Priyoto, 2014). The results of this study are in line with the study of Smith et al. (2011) which states that parents who do not immunize their children are less likely to assume that the vaccine is safe compared to parents who immunize their children.

There are many obstacles that one must go through to be able to take a health action. Before adopting a behavior, one must believe that the magnitude of the obstacles experienced when taking preventive action is smaller than the consequences of the action or the old behavior. For example, from the experience of parents that they did not receive immunization but were healthy, and they had to take new actions, namely to carry out immunization actions to their children, they must believe that the obstacles and consequences of immunization are smaller than other preventive measures such as maintaining hygiene. Therefore, it is necessary to instill an understanding to mothers about the difference between old and new behaviors and the spread of disease in their environment.

\section{REFERENCE}

$\overline{\text { Arfianto (2012). Orangtua cermat, anak se- }}$ hat (Careful parents, healthy children). Jakarta: Gagas Media. 
Journal of Health Promotion and Behavior (2016), 1(3): 212-223

https://doi.org/10.26911/thejhpb.2016.01.03.08

Arief M (2008). Pengantar metodologi penelitian untuk ilmu kesehatan (Introduction to research methodology for health sciences). Surakarta: LPP dan UNS press.

Babalola S, Lawan U (2009). Factors predicting BCG immunization status in northern Nigeria: a behavioral-ecological perspective. Journal Child Health Care 13 (1): 46-62.

Brieger WR (2006). Health belief model, social learning theory. Retrieved from ocw.jhsph.edu. Accessed on 12 Desember 2015 .

Burke E (2013). The health belief model. Retrieved from www.iccwa.org.au. Accessed on 12 Desember 2015.

Cahyono, JB (2010). Vaksinasi cara ampuh cegah penyakit infeksi. Yogyakarta: Kanisius.

Cerutti M, Lonlay PD, Menni F, Parini R, Principi N, Esposito S (2015). Vaccination coverage of patients with inborn errors of metabolism and the attitudes of their parents toward vaccines. Vaccine Journal. 33 (28): 6520-6524.

Chalidyanto D, Nurida A (2012). Hubungan tingkat kematangan social capital dengan pencapaian target Universal Child Immunization (UCI) di wilayah health center kota Surabaya (The relationship between the level of maturity of social capital with the achievement of Universal Child Immunization (UCI) targets in the health center area of the city of Surabaya). Jurnal Administrasi Kebijakan Kesehatan. 10 (1): 1-5.

Chen JY, Fox SA, Cantrell CH, Stockdale SE, Kagawa-Singer M (2007). Health disparities and prevention: racial/ ethnic barriers to flu vaccination. Journal Community Health. 32(1): 5-
20. Retrieved from www.ncbi.nlm.nih. gov. Accessed Juni 2016.

Desmita. (2011). Psikologi perkembangan peserta didik (Developmental psychology of students). Bandung: Remaja Rosda Karya .

Dinkes Surakarta (2014). Profil kesehatan Kota Surakarta 2014 (2014 Surakarta City health profile). Surakarta: Dinas Kesehatan Kota Surakarta.

Dinkes Surakarta (2014). Plan of action Health center Banyuanyar. Surakarta: Dinas Kesehatan Kota Surakarta.

Dinkes Surakarta (2014). Plan of action Health center Penumping tahun 2014. Surakarta: Dinas Kesehatan Kota Surakarta.

Dinkes Kebumen (2013). Sekilas tentang imunisasi DPT-HB-Hib (Overview of DPT-HB-Hib immunization). www.dinkeskebumen.wordpress.com. Accessed Februari 2016.

Doshi RH, Shidi C, Mulumba A, Eckhoff P, Nguyen C, Hoff NA, Gerber S (2015). The effect of immunization on measles incidence in the Democratic Republic of Congo: Result from a model of surveilance data. Vaccine Journal 33: 6786-6792.

Dupati A, Egbers RG, Helfrich YR (2015). A case of incontinentia pigmenti reactivation after 12-month immunizations. JAAD Case Report 1: 351-532.

Febriastuti N, Arif YS, Kusumaningrum T (2013). Kepatuhan orang tua dalam pemberian kelengkapan imunisasi dasar pada bayi 4-11 bulan (Parent compliance in providing basic immunization to infants 4-11 months). Program Studi S1 Pendidikan Ners Fakultas Keperawatan Universitas Airlangga. Retrieved from www.journal.unair.ac.id. Accessed on 16 Juni 2016.

Fajriyah I. 2014. Hubungan pengetahuan ibu dan dukungan keluarga dengan 
status imunisasi TD pada sub pin difteri (Relationship between mother's knowledge and family support with TD immunization status in diphtheria sub-pin). Jurnal Berkala Epidemiologi 2(3): 404-415.

Gibson DG, Ochieng B, Kagucia EW, Obor D, Odiambo F, O’Brien KL, Feikin DR (2015). Individual level determinants for not receiving immunization, receiving immunization with delay, and being severely underimmunized among rural western Kennyan children. Vaccine Journal 33: 6778-6785.

Glanz JM, Newcomer SR, Jackson ML, Omer SB, Bednarczyk RA, Shoup JA, DeStefano F (2015). White Paper on studying the safety of the childhood immunization schedule in the Vaccine Safety Datalink. Vaccine Journal. 345: A1-A29.

Gristwood J (2011). Applying the health belief model to physical activity engagement among older adult. Illuminare: A Student Journal in Recreation, Parks, and Leisure Studies 9(1): 59-71. Hadinegoro SR (2015). Menutup senjang imunisasi, perspektif Ikatan Dokter anak Indonesia (Closing the immunization gap, the perspective of the Indonesian Pediatric Association). Retrieved from www.idai.or.id. on 14 Juni 2016.

Hayden J (2009). Introduction to health behaviour theory. USA: Jones and Bartlett Publisher.

Hayden J (2010). Health belief theory. USA: Jones and Bartlett Publisher.

Hidayat AAA (2007). Siapa bilang anak sehat pasti cerdas (Who said healthy children must be smart). Jakarta: Elex Media Computindo.

Hidayat AAA (2009). Pengantar ilmu kesehatan anak untuk pendidikan kebidanan (Introduction to child health science for midwifery education). Jakarta: Salemba Medika.

Hikmarida F (2014). Keeratan penyimpanan dan pencatatan dengan kualitas rantai dingin vaksin DPT di health center (The closeness of storage and recording with the quality of the DPT vaccine cold chain at the health center). Jurnal Berkala Epidemiologi 2(3): 380-391.

Ismet F (2013). Analisis faktor yang berhubungan dengan imunisasi dasar lengkap pada bayi di Desa Batubarani Kecamatan Kabila Bone Kabupaten Bone Bolango (Factor analysis related to complete basic immunization in infants in Batubarani Village, Kabila Bone District, Bone Bolango Regency). Jurnal Keperawatan UNG. Fakultas Ilmu Kesehatan dan Keolahragaan Universitas Negeri Gorontalo. Retrieved from www.digilib.esaunggul.ac.id. Accessed November 2015.

IDAI (2013). Imunisasi penting untuk mencegah penyakit berbahaya (Immunization is important to prevent dangerous diseases). Retrieved from www.idai.or.id.

IDAI (2014). Jadwal imunisasi anak umur 0-18 tahun rekomendasi Ikatan Dokter Anak Indonesia (IDAI) Tahun 2014 (Immunization schedule for children aged o-18 years recommended by the 2014 Indonesian Pediatrician Association (IDAI)). Retrieved from www.idai.or.id. Accessed on 11 November 2015.

IDAI (2015). Melengkapi/ mengejar imunisasi (Complete/pursue immunization). Retrieved from www.idai.or.id. Accessed on 11 November 2015.

Jit M, Huyen DTT, Friberg I, Minh HV, Kiet PHT, Walker N, Cuong NV (2015). Thirty years of vaccination in Vietnam: Impact and cost-effectiveness of 
Journal of Health Promotion and Behavior (2016), 1(3): 212-223

https://doi.org/10.26911/thejhpb.2016.01.03.08

the national Expanded Programme on Immunization. Vaccine Journal 33: A233-A239.

Kadir L, Fatimah, Hadia (2014). Pengetahuan dan kepatuhan ibu dalam pemberian imunisasi dasar bagi bayi (Knowledge and compliance of mothers in providing basic immunizations for infants). Journal of Pediatric Nursing I (I): 009-013.

Kemenkes RI (2010). Gerakan Akselerasi Imunisasi Nasional Universal Child Immunization 2010-2014 (GAIN UCI 2010-2014) (Universal Child Immunization National Immunization Acceleration Movement 2010-2014 (GAIN UCI 2010-2014). Retrieved from www.perpustakaan.depkes.go.id.

Accessed on 11 November 2015.

Kemenkes RI (2014). Situasi dan analisis imunisasi (Situation and immunization analysis). Retrieved from www.depkes.go.id. Accessed on 11 November 2015 .

Kemenkes RI (2014). Lindungi ibu dan bayi dengan imunisasi (Protect mother and baby with immunizations). Retrieved from www.depkes.go.id. on 11 November 2015.

Kemenkes RI (2015). Data dan informasi tahun 2014 (2014 data and information) (profil kesehatan Indonesia). Retrieved from www.depkes.go.id. Accessed on 11 November 2015.

Luthy KE, Beckstrand RL, Callister LC (2009). Parental hesitation as a factor in delayed childhood immunization. Journal Pedriatic Health Care 23(6): 388-393.

Maharani D (2015). Imunisasi adalah hak anak (Immunization is the right of children). Retrieved from www.kompas.com. Accessed on 14 Juni 2016.

Maharani RA (2013). Supportive pediatric programs at Kampai Tabu Karimbia community health centre towards MDGS 2015. Folia Medica Indonesiana 49(1): 36-41.

Maryunani A. 2010. Ilmu kesehatan anak dalam kebidanan (Child health science in midwifery). Jakarta: Trans Info Media.

Mir O, Adam J, Gaillard R, Gregory T, Veyrie $\mathrm{N}$, Yordanov $\mathrm{Y}$, Berveiller $\mathrm{V}$ (2012). Vaccination coverage among medical residents in Paris, France. Clinical Microbiology and Infection Journal 18 (5): E137-E139.

Mubarak WI (2011). Promosi kesehatan untuk kebidanan (Health promotion for midwifery). Jakarta: Salemba Medika.

Mubarak WI (2012). Ilmu kesehatan masyarakat konsep dan aplikasi dalam kebidanan. Jakarta: Salemba Medika.

Murti B (2013). Desain dan ukuran sampel untuk penelitian kuantitatif dan kualitatif di bidang kesehatan (Design and sample size for quantitative and qualitative research in the health field). Yogyakarta: Gajah Mada University Press

Murti B (2015). Path analysis. Interview by Dwi Ertiana. Gedung Pascasarjana UNS.

Nelas P, Duarte J, Chaves C, Coutinho E, Amaral O (2015). Health belief about cervical cancer in university students. Procedia-Social and Behavioral Sciences, 165: 189-194.

Namdi OA, Chinedum OU, Shedrack EO, Ugochukwu NC, Okechukwu EC (2015). An asesment, in mice, of the safety of the childhood immunization vaccines sourced from three southeastern states of Nigeria. Trials in Vaccinology Journal 5: 8-14.

Namdi OA, Uchenna AR, Chinnedum OU, Ogochukwu NC, Shedrack EO, Okechukwu EC (2015). Safety evaluation in mice of the childhood immuniza- 
tion vaccines from two south-eastern states of Nigeria. Asian Pacific Journal of Tropical Biomedicine 5(2): 132137.

Noorkasiani, Heryati, Ismail R (2009). Sosiologi Keperawatan (Nursery Sociology). Jakarta:EGC.

Nugroho $T$ (2011). Asuhan keperawatan maternitas, anak, bedah, penyakit dalam (Maternity, child care, surgery, internal medicine). Yogyakarta: Nuha Medika.

Octaviani JA, Hargono A (2015). Penolakan ibu bayi terhadap pemberian imunisasi dasar di wilayah Health center Kamoning Sampang (Rejection of infant mothers against basic immunization in the Kamoning Sampang Health Center area). Jurnal Promkes 3(1): 67-68.

Okoro JC, Ojinnaka NC, Ikefuna AN, Onyenwe NE (2015). Sociodemographic influences on immunization of children with chronic neurological disorders in Enugu, Nigeria. Trials in Vaccinologi Journal 4: 9-13.

Omer SB, Richards JL, Madhi SA, Tapia MD, Steinhoff MC, Aqil AR, kar N (2014). Three randomized trials of maternal influenza immunization in Mali, Nepal, and South Africa: Methods and expectations. Vaccine Journal 33: 3801-3812.

Orji R, Vassileva J, Mandryk R (2012). Toward and effective health interventions design: An extension of the health belief model. Online Journal of Public Health Informatics. Retrieved from www.hci.usask.ca. Accessed on 12 Desember 2015.

Orkarsson Y, Gudnason P, Jonsdottir GA, Kristinsson KG, Briem H, Haraldsson A (2015). Public opinion on childhood immunisations in Iceland. Vaccine Journal 33: 7211-7216.
Perez DM, Garcia FJA, Fernandez JA, Ortega MJC, Rauet JMC, Sanchez NG, Merino AH (2015). Immunisation schedule of the Spanish Association of Pediatrics: 2016 recommendation. Anales de Pediatria Journal 84 (1): 6o.e1-6o.e13.

Probandari AN, Handayani S, Laksono NJO (2013). Modul field lab edisi revisi II keterampilan imunisasi Fakultas Kedokteran Universitas Sebelas Maret Surakarta (Field revision edition module II immunization skills Faculty of Medicine, Sebelas Maret University: Surakarta.

Proverawati (2010). Imunisasi dan vaksinasi (Immunization and vaccination). Yogyakarta: Nuha Medika.

Priyoto (2013). Teori sikap dan perilaku dalam kesehatan (Theory of attitude and behavior in health). Yogyakarta: Nuha Medika.

Puspitasari DE, Syahrul F (2014). Faktor risiko pneumonia pada balita berdasarkan status imunisasi campak dan status ASI eksklusif (Risk factors for pneumonia in infants are based on measles immunization status and exclusive breastfeeding status). Jurnal Berkala Epidemiologi 3(1): 69-81.

Rahmawati AI (2014). Faktor yang mempengaruhi kelengkapan imunisasi dasar di kelurahan krembengan utara (Factors that influence the completeness of basic immunization in the north Krembengan village). Jurnal Berkala Epidemiologi 2(1): 59-70.

Romano V, Scott I (2014). Using health belief model to reduce obesity amongst African American and Hispanic populations. Procedia - Social and Behavioral Science 159(23): 710-711.

Saitoh A, Nagata S, Tsukahara Y, Vaida F, Sonobe T, Kamiya $H$, Naruse $T$ (2013). Perinatal immunization edu- 
cation improves immunization rates and knowledge: a randomized controlled trial. Preventive Medicine Journal 56(6): 386-405.

Sarimin S, Ismanto AY, Worang R (2014). Analisis faktor-faktor yang berhubungan dengan perilaku ibu dalam pemberian imunisasi dasar pada balita di Desa Taraitak Satu Kecamatan Langowan Utara Wilayah Kerja Health center Walantakan (Analysis of factors related to maternal behavior in providing basic immunization to children under five in Taraitak Satu Village, Langowan Utara District Walantakan Health Center Work Area). Skripsi Program Studi Ilmu Keperawatan Universitas Sam Ratulangi Manado. Retrieved from www.ejournal.unsrat.ac.id. Accessed on 16 Juni 2016.

Setiawan A (2010). Metodologi penelitian kebidanan DIII, DIV, S1, dan S2 (Research methodology for midwifery DIII, DIV, S1, and S2). Yogyakarta: Nuha Medika.

Slameto (2010). Belajar dan faktor-faktor yang mempengaruhinya (Learning and the factors that influence it). Jakarta: Rineka Cipta.

Smith PJ, Humistog SG, Marcuse SK, Zhao Z, Dorell CG, Howes C (2011). Parental delay or refusal of vaccine doses childhood vaccination coverage at 24 months of age, and the health belief model. Public Health Rep 2: 135-146.

Sopiyudin M (2012). Statistik untuk kedokteran dan kesehatan deskriptif, bivariat, dan multivariat dilengkapi aplikasi dengan menggunakan SPSS (Statistics for medicine and health are descriptive, bivariate, and multivariate with application using SPSS). Jakarta: Salemba Medika
Supriyanto S, Ashar F (2013). Rekomendasi upaya peningkatan kepatuhan imunisasi dengan pendekatan interaction model of client behaviour (IMCHB). (Recommendations for efforts to increase immunization compliance using the interaction model of client behavior (IMCHB) approach). Jurnal Administrasi Kebijakan Kesehatan 11 (2): 55-59.

Suririnah (2009). Buku pintar merawat bayi o-12 bulan (Smart book caring for babies 0-12 months). Jakarta: Gramedia Pustaka Utama.

Susanti FT (2013). 132 jawaban dokter untuk perawatan \& perkembangan bayi (o-12 bulan) (132 doctor answers for baby care \& development (0-12 months). Jakarta: Anak Kita.

Swardana NF, Wahyuni CU (2014). Faktor yang mempengaruhi ibu terhadap ketidakikutsertaan batita pada sub pin difteri (Factors that influence mothers to the absence of toddlers in diphtheria sub pins). Jurnal Berkala Epidemiologi 2(2): 227-239.

Syaifuddin AA (2008). Tips merawat kesehatan anak (Tips for caring for children's health). Yogyakarta: Media Ilmu.

Taylor D, Bury M, Campling N, Carter S, Garfied S, Newbould J, Rennie T (2007). A review of the use of the health belief model (HBM), the theory of reasoned action (TRA), the theory of planned behaviour (TPB) and the trans-theoritical model (TTM) to study and predict health related behaviour change.

Triana V (2016). Faktor yang Berhubungan dengan Pemberian Imunisasi Dasar Lengkap pada Bayi Tahun 2015. Jurnal Kesehatan Masyarakat Andalas. 10(2) (Factors Associated with the Provision of Complete Basic Immuni- 
zation in Infants in 2015. Andal Community Health Andalas. 10 (2). Retrieved from www.jurnal.fkm.unand.ac.id. Accessed on 16 Juni 2016.

Triharinni T, Isvandiari MA (2014). Analisis faktor yang terkait test tuberculin pada anak dengan riwayat kontak TB (Analysis of factors related to the tuberculin test in children with a history of contact TB). Jurnal Berkala Epidemiologi 2(2): 150-160.

Utama F, Chatarina UW, Martini S (2013). Determinan kejadian difteri klinis pasca sub pin difteri tahun 2012 di kabupaten Bangkalan (Determinants of clinical diphtheria events in post-pin diphtheria 2012 in Bangkalan district). Jurnal Berkala Epidemiologi 2(1): 71-82.

Verguet S, Johri M, Morris SK, Gauvreau CL, Jha P, Jit M (2015). Controlling measles using supplemental immunization activities: A mathematical model to inform optimal policy. Vaccine Journal 33: 1291-1296.

Wardana DS (2013). Motivasi berprestasi dengan kinerja guru yang sudah disertifikasi. Jurnal Ilmiah Psikologi (Achievement motivation with the performance of teachers who have been certified. Journal of Scientific Psychology) Terapan 01 (01): 97-107.

Walgito B (2010). Pengantar Psikologi Umum. Yogyakarta: CV Andi Ofset.

Waluyanti FT (2009). Analisis faktor kepatuhan imunisasi di kota Depok. Tesis Program Magister Ilmu Keperawatan Anak Program Studi Pascasarjana Fakultas Ilmu Keperawatan (Analysis of immunization compliance factors in the city of Depok. Thesis of the Child Nursing Masters Program Postgraduate Study Program Faculty of Nursing). Retrieved from www.lib.ui.ac.id. Accessed on 11 November 2015.

Wang WN, Hsu SD, Wang JH, Huang LC, Hsu WL (2014). Survey of breast cancer mammography screening behaviors in Eastern Taiwan based on health belief model. Kaohsiung Journal of Medical Sciences 30: 422-427.

Widjaja MC (2008). Mencegah dan mengatasi demam pada balita (Prevent and overcome fever in toddlers). Jakarta: Kawan Pustaka.

Widoyono (2011). Penyakit tropis epidemiologi, penularan, pencegahan, and pemberantasannya edisi kedua (Second edition of tropical epidemiology, transmission, prevention and eradication). Jakarta: Erlangga.

Wilkinson, JM (2011). Buku saku diagnosis keperawatan (9nd ed) (Nursing diagnosis pocket book (9nd ed). Jakarta: EGC.

Xi L, Wiesen E, Diorditsa S, Toda K, Duong TH, Nguyen LH, Nguyen VC (2015). Impact of Adverse Events Following Immunization in Viet Nam in 2013 on chronic hepatitis B infection. Vaccine Journal 34: 869-873.

Zetu L, Zetu I, Dogaru CB, Duta C, Dumitrescu AL (2013). Gender variations in the psychological factors as defined by the extended health belief model of oral hygiene behaviors. Procedia - Social and Behavioral Sciences. 127: 358-362.

Zipurski S, Djingarey MH, Lodjo JC, Olodo L, Tiendrebeogo S, Ronveaux O (2013). Benefits of using vaccines out of the cold chain: Delivering Meningitis, A vaccine in a controlled temperature chain during the mass immunization campaign in Benin. Vaccine Journal 32: 1431-1435. 